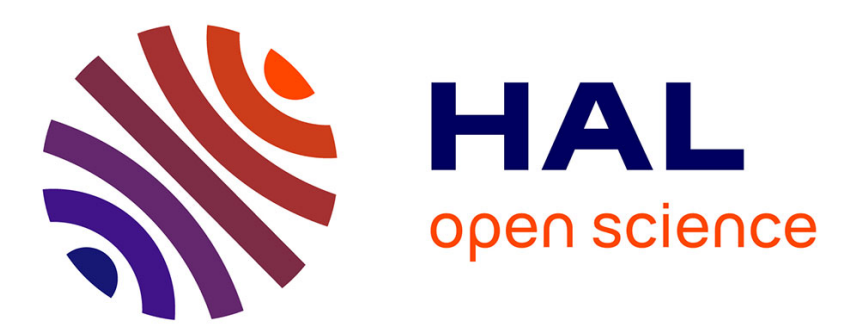

\title{
Independent Control of Two Induction Motors Fed by a Five Legs PWM Inverter for Electric Vehicles
}

Bekheira Tabbache, Kamel Rebaa, Khoudir Marouani, Mohamed Benbouzid, Abdelaziz Kheloui

\section{> To cite this version:}

Bekheira Tabbache, Kamel Rebaa, Khoudir Marouani, Mohamed Benbouzid, Abdelaziz Kheloui. Independent Control of Two Induction Motors Fed by a Five Legs PWM Inverter for Electric Vehicles. IEEE POWERENG 2013, May 2013, Istanbul, Turkey. pp.629-634. hal-00926296

\section{HAL Id: hal-00926296 https://hal.science/hal-00926296}

Submitted on 9 Jan 2014

HAL is a multi-disciplinary open access archive for the deposit and dissemination of scientific research documents, whether they are published or not. The documents may come from teaching and research institutions in France or abroad, or from public or private research centers.
L'archive ouverte pluridisciplinaire HAL, est destinée au dépôt et à la diffusion de documents scientifiques de niveau recherche, publiés ou non, émanant des établissements d'enseignement et de recherche français ou étrangers, des laboratoires publics ou privés. 


\title{
Independent Control of Two Induction Motors Fed by a Five Legs PWM Inverter for Electric Vehicles
}

\author{
B. Tabbache ${ }^{1}$, K. Rebaa ${ }^{1}$, K. Marouani ${ }^{1}$, M.E.H. Benbouzid ${ }^{2}$ and A.Kheloui ${ }^{1}$ \\ ${ }^{1}$ Laboratoire Commande des machines electriques, UER : ELT-Eole Militaire Polytechnique, Algiers (Algeria) \\ ${ }^{1}$ University of Brest, EA 4325 LBMS Brest, France \\ E-mails: laid tabache@yahoo.com, Mohamed.Benbouzid@univ-brest.fr
}

\begin{abstract}
This paper deals with the implementation of an independent control of two induction motors fed by five legs PWM inverter. In this context, two Pulse Width Modulation techniques are presented in order to be included in the indirect field oriented control algoritm. Experiments and simulation are carried-out, on an induction motor drive, to show that the developed independ control of five legs inverter is effective and provides a simple configuration with high performance in terms of speed and torque responses.
\end{abstract}

Index Terms- converter multi-machine System, Five legs Inverter, Pulse Width Modulation (PWM), DSP Board (eZdsp F2812),

\section{NOMENCLATURE}

\begin{tabular}{|c|c|c|}
\hline \multicolumn{2}{|c|}{$E V=$} & Electric vehicle; \\
\hline \multirow{2}{*}{\multicolumn{2}{|c|}{$\begin{array}{l}I M= \\
\text { IFOC }=\end{array}$}} & Induction motor; \\
\hline & & Indirect field oriented control; \\
\hline \multicolumn{2}{|c|}{$\mathrm{PWM}=$} & Pulse width modulation; \\
\hline \multicolumn{2}{|c|}{$\mathrm{FG}=$} & Fixed gear, \\
\hline \multicolumn{2}{|c|}{$s,(r)=$} & Stator (rotor) index; \\
\hline \multicolumn{2}{|c|}{$\alpha, \beta=$} & Synchronous reference frame index; \\
\hline \multicolumn{2}{|c|}{$\mathrm{a}, \mathrm{b}, \mathrm{c}=$} & Three phases reference frame index; \\
\hline \multicolumn{2}{|c|}{$V(I)=$} & Voltage (Current); \\
\hline \multirow{2}{*}{\multicolumn{2}{|c|}{$\begin{array}{l}R= \\
L\left(L_{m}\right)=\end{array}$}} & Resistance; \\
\hline & & Inductance (Magnetizing inductance); \\
\hline \multirow{2}{*}{\multicolumn{2}{|c|}{$\begin{array}{l}\sigma \\
T_{r}\end{array}$}} & Leakage coefficient, $\sigma=1-L_{m}{ }^{2} / L_{s} L_{r}$ \\
\hline & & Rotor time constant $\left(T_{r}=L_{r} / R_{r}\right)$ \\
\hline & $=$ & Stator time constant $\left(T_{s}=L_{s} / R_{s}\right)$; \\
\hline & $=$ & pole-pair number. \\
\hline$v$ & $=$ & Vehicle speed; \\
\hline & $=$ & Road load; \\
\hline & $=$ & Rolling resistance force; \\
\hline & $=$ & Stokes or viscous friction force; \\
\hline & $=$ & Aerodynamic drag force; \\
\hline & $=$ & Climbing and downgrade resistance force; \\
\hline & $=$ & Vehicle driving power; \\
\hline$J$ & $=$ & Total inertia (rotor and load); \\
\hline \multirow{2}{*}{\multicolumn{2}{|c|}{$\begin{array}{l}\omega_{m}= \\
T_{B}=\end{array}$}} & Electric motor mechanical speed; \\
\hline & & Load torque accounting for friction and \\
\hline \multicolumn{3}{|c|}{ dage; } \\
\hline & $=$ & Load torque; \\
\hline & $=$ & Electric motor torque; \\
\hline & $=$ & Transmission ratio; \\
\hline & $=$ & Transmission efficiency; \\
\hline & $=$ & Reference index; \\
\hline & $=$ & Steering angle; \\
\hline
\end{tabular}

\section{INTRODUCTION}

Today multi-converter multi-motor systems occupy an important place in industry applications such as electric powertrain, textile paper industries and autonomous mobile. Recently, reliably, efficiency and economic factors become more and more necessary to design the control of these systems .In other hand, research efforts have been made to reduce the number of power electronic devices required in multi-motor drive systems, to reduce the overall complexity, therefore the powertrain cost and the possibility to operate the system in fault condition.

Multi-motor multi-converter system can be composed by converter supplying several machines or many converters fed only one machine or, the combination of these two possibilities.

Most of these inverters use insulated IGBTs as the power device. Indeed, in the event of a failure in the power inverter, the conventional EV powertrain topology cannot ensure the vehicle traction operation. Therefore, the need to develop decoupling control of five leg inverter is highly desirable. In this case, during post-fault operation, the faulty leg is isolated by a specific switch (i.e. fast-acting fuse) and the drive operates therefore with five legs inverter.

In this context, this paper describes an independent control of two induction motors fed by five legs inverter. Experiments and simulations on an induction motor drive are carried-out to show that the developed independent control of five legs inverter is effective and provides a simple configuration with high performance in terms of speed and torque responses.

\section{ELECTRIC VEHICLE AND DUAL-MOTOR CONFIGURATION}

There are several possible EV configurations regarding the electric propulsion and the energy sources [1]. In the adopted dual-motor configuration, tow three phase PWM inverters are associated to two induction motors in front of the electric vehicle.

The novel structure in this paper consist to associate only five legs inverter to drive the two induction motors as show by Fig .1.a.The advantages of this topology is to reduce the number of the power components and therefore the weight and the cost of the EV powertarin. In other hand, this structure can be used in event of an IGBT failure.

\section{A. Electric Vehicle Modeling and Dynamics Briefly}

The proposed strategy takes into account the EV aerodynamics, and is not applied to the sole induction motor. The vehicle model is based on mechanics and aerodynamics principles (Fig. 1) [2]. 


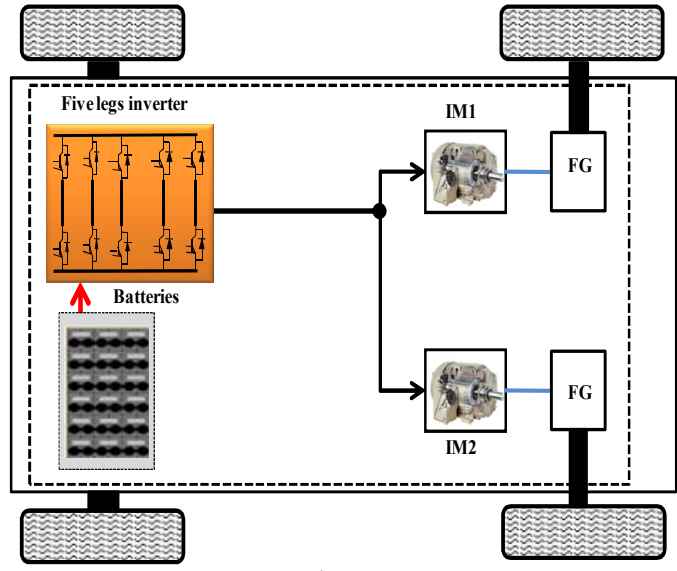

a)

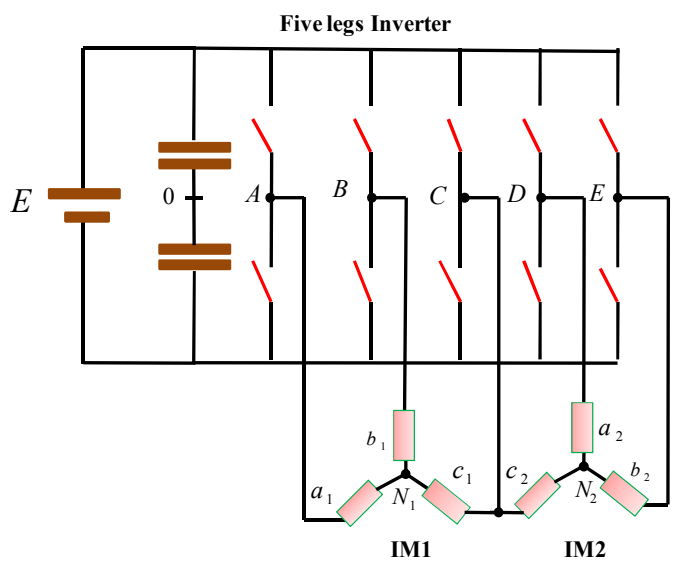

b)

Fig.1 EV dual induction motors fed by five leg inverters

The road load is then given by

$$
F_{w}=F_{r o}+F_{s f}+F_{a d}+F_{c r}
$$

The power required to drive the EV at a speed $v$ has to compensate the road load $F_{w}$.

$$
P_{v}=v F_{w}
$$

The mechanical equation (in the motor referential) used to describe each wheel drive is expressed by

$$
J \frac{d \omega_{m}}{d t}+T_{B}+T_{L}=T_{m}
$$

The following equation is derived due to the use of a reduction gear.

$$
\left\{\begin{array}{l}
\omega_{\text {Wheel }}=\frac{\omega_{m}}{i} \\
T_{\text {Wheel }}=T_{m} i \eta_{t}
\end{array}\right.
$$

\section{VECTOR REPRESENTATION OF FIVE LEGS PWM INVERTER}

In general, two induction motors are supplied by two classical three phase inverters. This system requires twelve (12) controllable power switches (IGBTs-Isolated Gate Bipolar Transistor) to operate with independent variable speed of the two motors. In event of power switch failure, the corresponding leg should be isolated. In this case, the two classical three phases form one inverter composed of five legs. In other hand, the operation of more industry applications should be ensured by five legs inverter. This inverter used also in specified application in order to reduce the power switches compared to the two classical inverters.

Fig.1.b shows the five legs inverter fed two induction motors. This structure uses a common leg for supplying in the same time two induction motors phases. In Figure1.b, leg $\mathrm{C}$ is used as a common leg.

The voltage vector applied to the two induction motors in Concordia frame $(\alpha, \beta)$ of the five legs inverter is defined by the following equation.

$$
\begin{aligned}
\bar{V}_{s} & =V_{s \alpha}+j V_{s \beta} \\
& =\sqrt{\frac{2}{5}} E\left(V_{a}+V_{b} \cdot \exp \left(\frac{j 2 \pi}{5}\right)+V_{c} \cdot \exp \left(\frac{j \pi}{5}\right)+V_{d} \cdot \exp \left(\frac{j 6 \pi}{5}\right)+V_{e} \cdot \exp \left(\frac{j \pi}{5}\right)\right)
\end{aligned}
$$

with $V_{a}, V_{b}, V_{c}, V_{d}$ and $V_{e}$ are the inverter voltages.

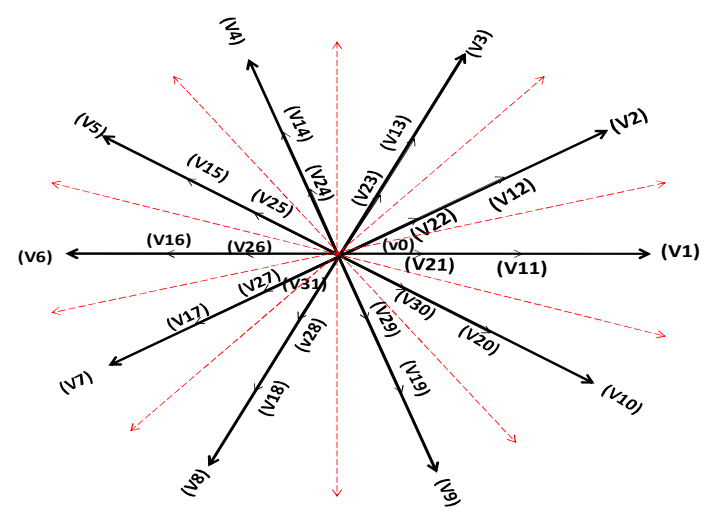

Fig.2 Vector representation of five legs inverter

Five legs inverter have $2^{5}$ (32) different voltage vectors that each switch have only two possible states (open or closed) (Fig.2) [3].

\section{INDEPENDENT CONTROL OF TWO INDUCTION MOTORS FED BY FIVE LEGS INVERTER}

The control scheme of the induction motor associated to the five legs inverter is presented in Fig.3. It is based on two classical indirect field oriented control for each motor and a specified Pulse Width Modulation (PWM) of five legs inverter.

\section{A. Indirect field oriented control (IFOC)}

IFOC aim is to decouple the flux and the torque control. To achieve this goal, the flux must be oriented on the $d$-axis in the $d-q$ frame [4].

$$
\left\{\begin{array}{l}
\phi_{r d}=\phi_{r} \\
\phi_{r q}=0
\end{array}\right.
$$




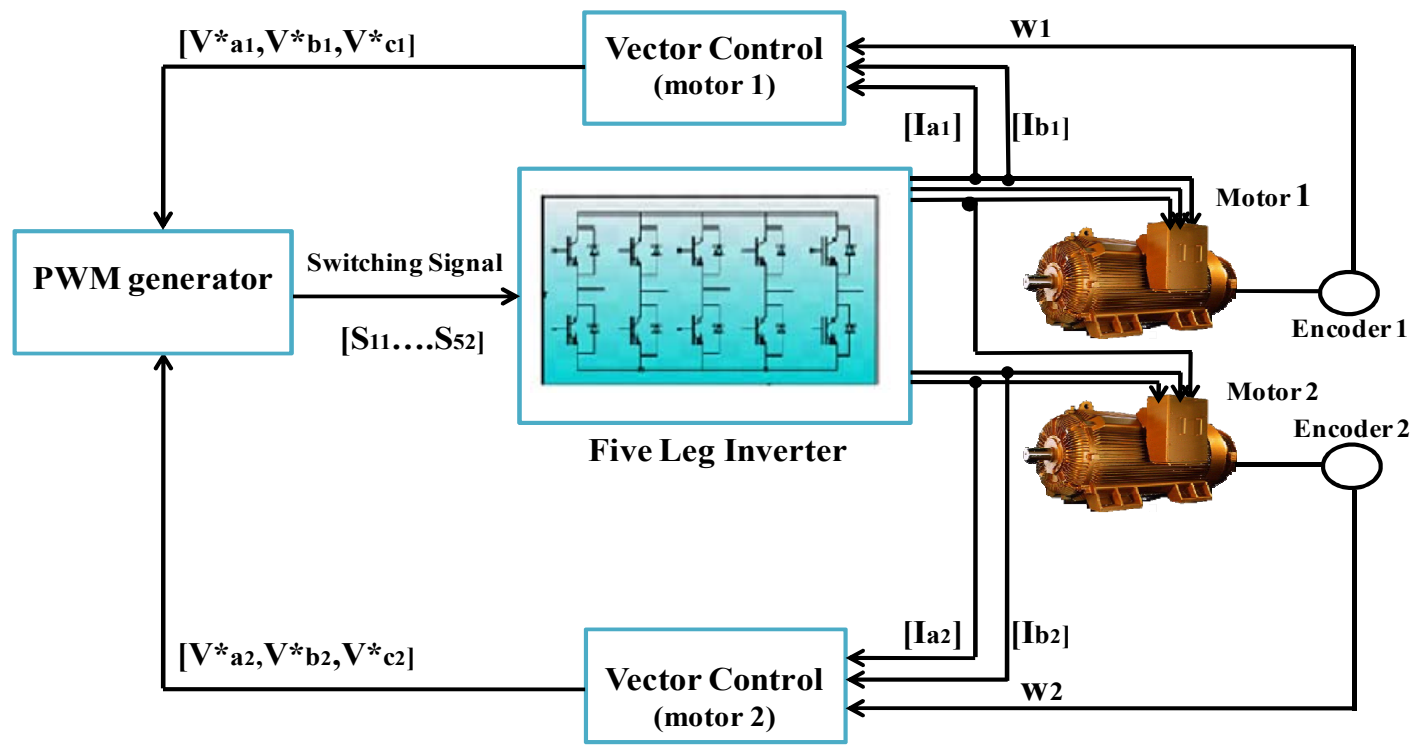

Fig.3 Independent control structure

The induction motor model in the $d$ - $q$ reference frame is then described by

$$
\left\{\begin{array}{l}
V_{s d}=R_{s} I_{s d}+\sigma L_{s} \frac{d I_{s d}}{d t}+\frac{M}{L_{r}} \frac{d \phi_{r}}{d t}-\omega_{s} \sigma L_{s} I_{s q} \\
V_{s q}=R_{s} I_{s q}+\sigma L_{s} \frac{d I_{s q}}{d t}+\omega_{s} \frac{M}{L_{r}} \phi_{r}+\omega_{s} \sigma L_{s} I_{s d} \\
T_{r} \frac{d \phi_{r}}{d t}+\phi_{r}=M I_{s d} \\
\omega_{s l}=\omega_{s}-\omega_{r}=\frac{M}{T_{r}} \frac{I_{s q}}{\phi_{r}}
\end{array}\right.
$$

The steady-state motor torque can be written as

$$
T_{e}=p \frac{M}{L_{r}} \phi_{r} I_{s q}
$$

In this paper, two PWM strategies will be presented. Each method is used in order to avoid the offset components in the motor torque.

\section{B. Pulse Width Modulation strategy based on the cancellation of the voltage reference}

In this paper, the five legs inverter fed two induction motors (Fig.1.b) which two phases share leg C. Legs A and $\mathrm{B}$ of the inverter are connected directly to the phases $\mathrm{a}_{1}$ and $\mathrm{b}_{1}$ of the first motor. Legs D and E are connected to the inverter phases $a_{2}$ and $b_{2}$ of the second motor. This technique is based on the cancellation of the single phase voltage connected to the common leg. For this, the reference voltages of the two motors can be written as:

$$
\left\{\begin{array}{l}
V_{A}^{*}=V^{*}{ }_{a 1}-V^{*}{ }_{c 1} \\
V_{B}^{*}=V_{b 1}^{*}-V^{*}{ }_{c 1} \\
V_{C}^{*}=V^{*}{ }_{c 1}=V^{*}{ }_{c 2}=0 \\
V_{D}^{*}=V^{*}{ }_{a 2}-V^{*}{ }_{c 2} \\
V_{E}^{*}=V_{b 2}^{*}-V^{*}{ }_{c 2}
\end{array}\right.
$$

The main drawback of this technique is the reduction of the maximum reference voltage by factor $1 / \sqrt{3}$ compared with the reference voltage in classical three phase systems [5].

\section{Pulse Width Modulation strategy based on the addition of the voltage reference}

This technique based on the addition of the reference voltage of the third phase reference voltages of second motor to the first one. The same principle is applied to the reference voltages of the second motor. The equations below illustrate the principle of this technique [6].

$$
\left\{\begin{array}{l}
V_{A}^{*}=V^{*}{ }_{a 1}+V^{*}{ }^{*} 2 \\
V_{B}^{*}=V^{*}{ }_{b 1}+V^{*}{ }_{c 2} \\
V_{C}^{*}=V^{*}{ }{ } 1+V^{*}{ }_{c 2} \\
V_{D}^{*}=V^{*}{ }_{a 2}+V^{*}{ }{ }^{* 1} \\
V_{E}^{*}=V^{*}{ }_{b 2}+V^{*}{ }{ }^{* 1}
\end{array}\right.
$$

In terms of dynamic performances, the both techniques present a promising solution in the control of five legs inverter. Nevertheless, the technique based on Cancellation of the reference voltage of the phase connected to the common leg decreases the reference voltages by a fixed ratio. While, the technique based on addition of the reference 
voltage of the phase connected to the common leg has a variable ratio according to the dynamic speed and torque.

\section{EXPRIMENT RESULTS}

\section{A. Test bench}

The test bench used to validate the proposed control strategies is illustrated by Fig.4. It main components, in addition to the induction motors and the DC machine are: 1) a DSP TMS320 development board interfaced to a standard PC, 2) an absolute encoder attached to the motor shafts, 3) Hall effect sensors for voltage and current measurements, 4) a five legs PWM inverter, 5) a DC-DC converter .

The load torque is provided by DC machine controlled as generator.

\section{B. Experimental results}

Experimental results are carried out to test the developed control technique of the five legs inverter.

Figure 5 illustrates the two induction motor speeds. As shown by this figure the developed technique ensures the separate control of the two induction motors.

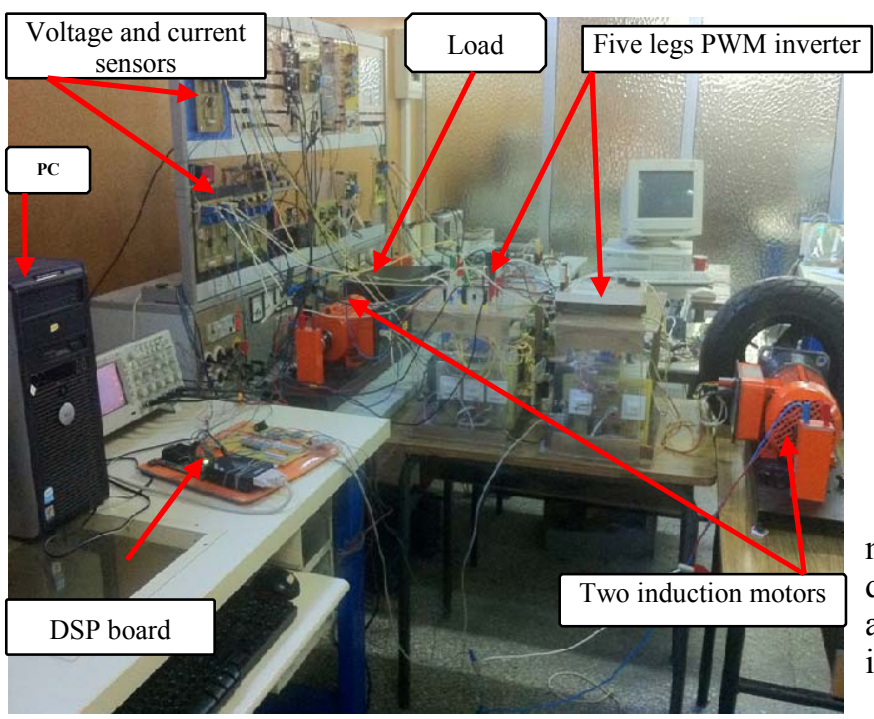

Fig.4 Test bench

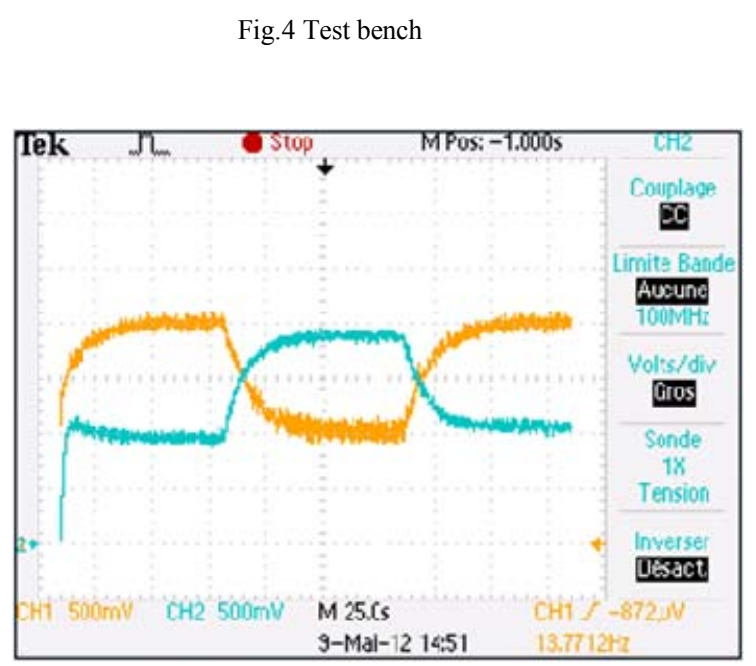

In the case when the induction motors operate at different speeds the current in the common leg is not sinusoidal (Fig.6). In the previous situation, both induction motors absorb sinusoidal currents as shown by Fig. 7 .
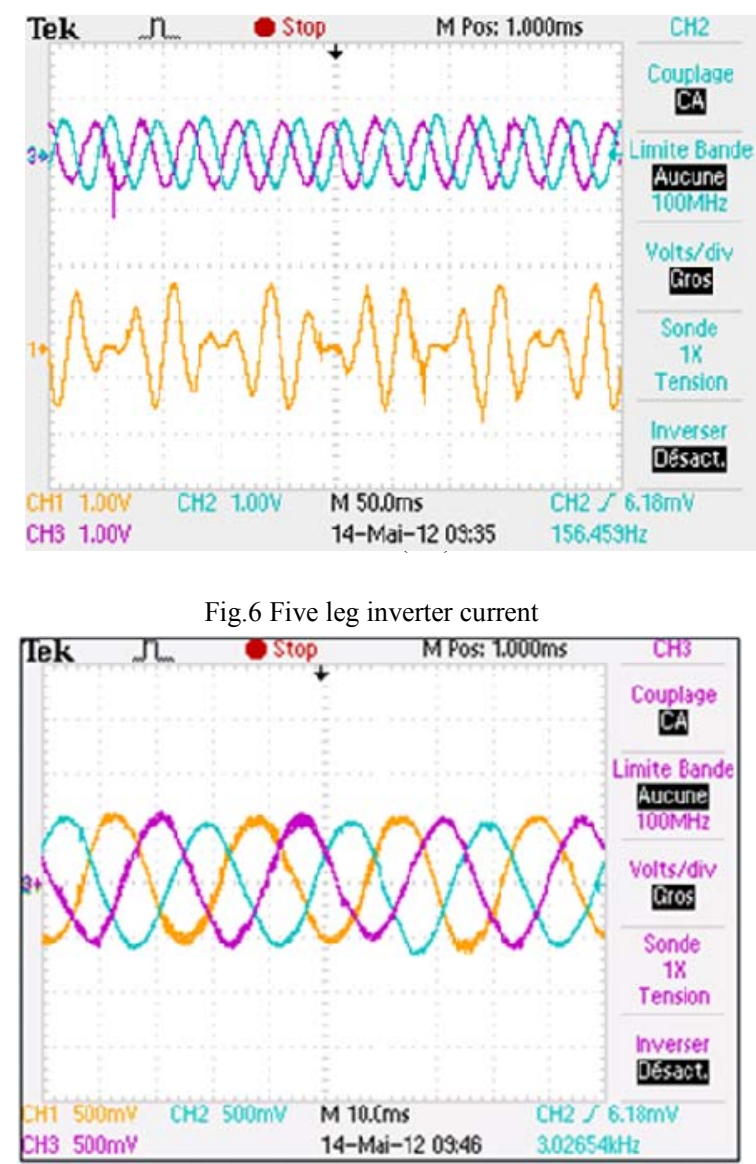

Fig.7 Induction motor currents

The line to line voltages applied to the two induction motors are illustaed in Fig.8.As shown by this figure, the devolloped control can save the same form of these voltages as in classical operation with two PWM inverters fed tow indution motors.

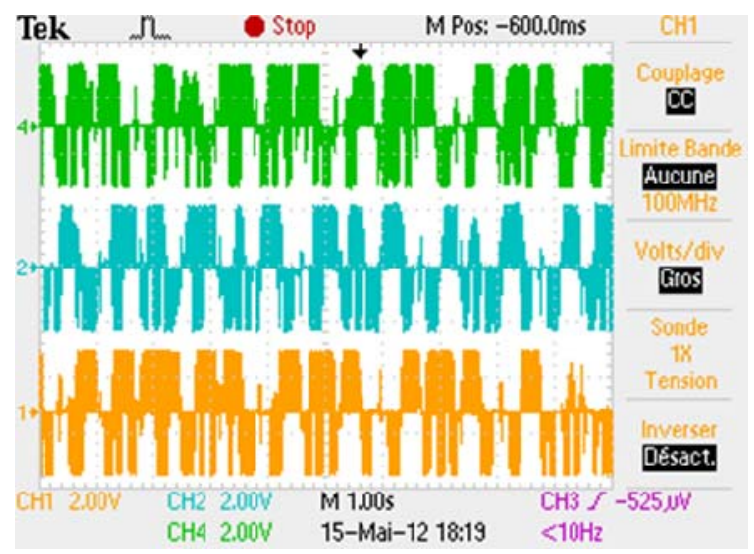

Fig.5 Induction motors speeds 


\section{EV DYNAMIC PERFORMANCES}

In order to evaluate the proposed independent control strategy performance, simulations have been carried-out on an electric vehicle using a $37-\mathrm{kW}$ induction motor based powertrain. The EV and the used cage induction motor rated data and parameters are given in the Appendix.

To evaluate the EV dynamic performances with five legs inverter, a series of tests in different load conditions were performed to emulate different type of traction behavior. For that purpose, a New European Driving Cycle (NEDC) is used as the speed reference.

\section{A. Electrical differential}

To handle EV stability while cornering or under slippery road condition, the two induction motors should be controlled by different speeds. In this context, the electric differential allows to provide the references speed of each induction motors.

The principle of the electric differential is show by Fig.9 [7]. As show by Fig.9, for the straight-line regime, the motor rotation speeds are the same value. For the turning regime, the rotation speeds for each motor are different [8].

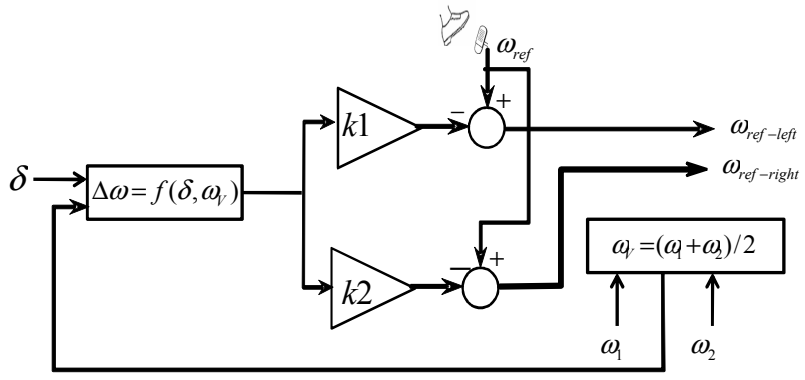

where $\Delta \omega$ is imposed when the vehicle crosses a turning way.

Fig.9 Electric differential scheme

\section{B. Experiment results}

In order to validate the proposed independent control with the electric differential, many scenarios are made.

Firstly, the electric vehicle cross a linear way which the both induction motors are the same reference speeds. Moreover, right and left turning respectively are simulated. In this case in two induction motors have different speeds.

The EV vehicle speed can be obtained through gear ration and wheel radius. In all the speed range, the proposed independent control provides the appropriate speed to the two wheels in order to maintain the EV best achievable performances.

In EV context, Simulations are carried-out using a European driving cycle (Fig.10).

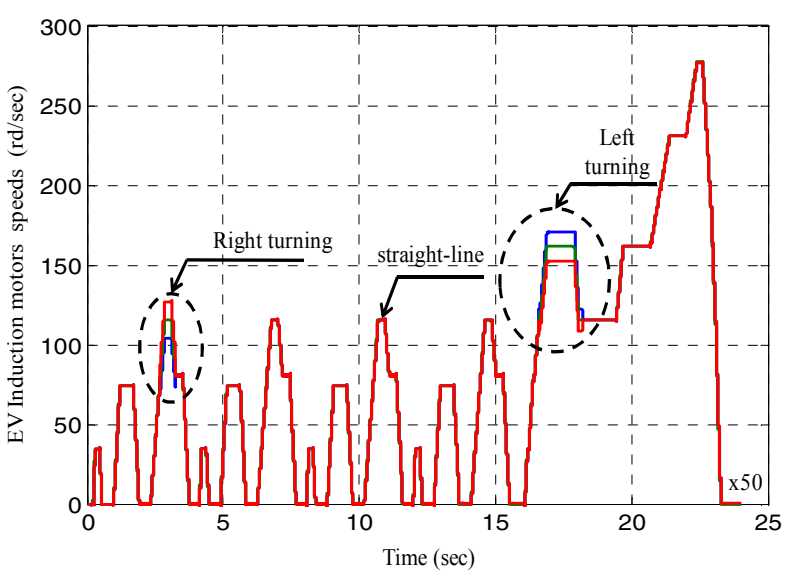

Fig.10. EV induction motors speeds

\section{CONCLUSION}

This paper describes an independent control for five legs fed two induction motors. The developed control can be used in event of power inverter failure in classical system with two three phases' inverters. In this context, two PWM strategies are presented. The first one is based on the cancellation of the reference voltage related to the common leg. In the second strategy the voltage is added to the others healthy phases. In term of performances, the both techniques present a promising solution for independent control of the five legs inverter. Nevertheless, the first technique increases the reference voltage with fixed ratio. While, the second one has a variable ratio according to the dynamics speed and torque.

Simulations and experiment on an induction motor drive are carried-out to show robustness of the developed control in terms of speed and torque responses.

\section{APPENDIX}

EV MECHANICAL AND AERODYNAMIC PARAMETERS

$$
\begin{gathered}
m=1540 \mathrm{~kg} \text { (two } 70 \mathrm{~kg} \text { passengers), } A=1.8 \mathrm{~m}^{2}, r=0.3 \mathrm{~m} \\
\mu_{r r 1}=0.0055, \mu_{r r 2}=0.056, C_{a d}=0.19, G=3.29, \eta_{g}=0.95 \\
v_{0}=4.155 \mathrm{~m} / \mathrm{sec}, g=9.81 \mathrm{~m} / \mathrm{sec}^{2}, \rho=0.23 \mathrm{~kg} / \mathrm{m}^{3}
\end{gathered}
$$

\section{RATED DATA OF THE SIMULATED INDUCTION MOTOR}

$$
\begin{gathered}
37 \mathrm{~kW}, 1480 \mathrm{rpm}, p=2 \\
R_{s}=0.0851 \Omega, R_{r}=0.0658 \Omega \\
L_{s}=0.0314 \mathrm{H}, L_{r}=0.0291 \mathrm{H}, L_{m}=0.0291 \mathrm{H}, \\
J=0.37 \mathrm{~kg} . \mathrm{m}^{2}, k_{f}=0.02791 \mathrm{Nmsec}
\end{gathered}
$$

\section{RATED DATA OF THE TESTED INDUCTION MOTOR}

$$
\begin{gathered}
1 \mathrm{~kW}, 2.5 \mathrm{Nm}, 2830 \mathrm{rpm}, p=1 \\
R_{s}=4.750 \Omega, R_{r}=8.000 \Omega, L_{s}=0.375 \mathrm{H}, L_{r}=0.375 \mathrm{H}, L_{m} \\
=0.364 \mathrm{H} \\
J=0.003 \mathrm{~kg} \cdot \mathrm{m}^{2}, k_{f}=0.0024 \mathrm{Nmsec}
\end{gathered}
$$




\section{REFERENCES}

[1] C. C. Chan, "The state of the art of electric, hybrid, and fuel cell vehicles," Proc. IEEE, vol. 95, no. 4, pp. 704-718, Apr. 2007.

[2] B. Tabbache, A. Kheloui and M.E.H. Benbouzid, "Design and control of the induction motor propulsion of an electric vehicle," in Proceedings of the 2010 IEEE VPPC, Lille (France), pp. 1-6, September 2010.

[3] L.Parsa,H.A.Toliyat "Sensorless Direct Torque Control of FivePhase Parmanent-Magnet Motor Drives ". IEEE Transaction on industry applications, Vol,43,N,4,July/August 2007.

[4] H. Rehman and $\mathrm{L}$. Xu, "Alternative energy vehicles drive system: Control, flux and torque estimation, and efficiency optimization," IEEE Trans. Vehicular Technology, vol. 60, n8, pp. 3625-3634, October 2011.

[5] Yuta Kimura et al, “ Independent Vector control of two PM Motors with Five-leg Inverter by the Expanded Tow-Arm Modulation Method". Dept of Electrical and Eectronic Engineering,M eiji University.

[6] M.Jones,S.N.Vukosavic,D.Dujic,E.Levi,P.Wright "Five-leg inverter PWM technique for reduced switch count two-motor constant power applications”.IET Electr.Power Appl.,2008,Vol. 2,No.5,pp.275-287.

[7] A. Haddoun, F. Khoucha, M. E. H. Benbouzid, and D. Diallo, "SDTC neural network traction control of an electric vehicle without differential gears," in Proc. IEEE VPPC, Arlington, TX, Sep. 2007, pp. 259-266.

[8] B. Tabbache, A. Kheloui and M.E.H. Benbouzid, "An adaptive electric differential for electric vehicles motion stabilization," IEEE Trans. Vehicular Technology, vol. 60, n ${ }^{\circ}$, pp. 104-110, January 2011. 